\title{
Hypernatraemia in Diarrhoeal Infants in Lagos
}

\author{
I. AHMED and T. B. AGUSTO-ODUTOLA \\ From the Department of Paediatrics, College of Medicine of the University of Lagos and \\ Lagos University Teaching Hospital, Lagos, Nigeria
}

\begin{abstract}
Ahmed, I., and Agusto-Odutola, T. B. (1970). Archives of Disease in Childhood, 45, 97. Hypernatraemia in diarrhoeal infants in Lagos. Records of 48 patients with acute gastro-enteritis who had a serum sodium concentration of $148 \mathrm{mEq} / 1$. or more have been reviewed. All except 3 were under 1 year of age and $62 \%$ were under 6 months. In the majority of patients no single cause for the hypertonicity of the body fluids could be identified, but general factors related to acute illness and continued feeding of the infants on powdered milk in addition to breast milk contributed. Excessive administration of saline was the probable cause in only 11 patients.

Twenty-two of the 48 patients had CNS manifestations; cerebral disturbances were commoner when the serum Na concentration was $158 \mathrm{mEq} / \mathrm{l}$. or more. 14 of the 48 patients died; with one exception all deaths occurred among patients with CNS manifestations. In view of the high risk of brain damage and mortality, the importance of prevention of hypernatraemia has been emphasized.
\end{abstract}

Hypernatraemia has been recognized in Western countries as a frequently occurring phenomenon in the fluid and electrolyte imbalance which accompanies infantile diarrhoea (Weil and Wallace, 1956; Macaulay and Blackhall, 1961; Bruck, Abal, and Aceto, 1968), but this association is believed to be rare in the tropics and in malnourished children, and reports are few, there being none from West Africa. Our experience in Lagos with patients suffering from diarrhoea led us to suspect that hypernatraemia was not at all rare and in the present paper we describe the condition as it occurs here.

\section{Subjects and Methods}

We reviewed the records of 48 children $(24$ male, 24 female) with diarrhoea seen in our hospital from December 1966 to May 1968, who showed a serum sodium concentration of $148 \mathrm{mEq} / \mathrm{l}$. or more. 30 were less than 6 months old; 13 were in the $6-9$ month group; 2 were between 9 months and 1 year; and only 3 children were above 1 year. The oldest child was $3 \frac{1}{2}$ years of age. Body weight was recorded in 23 patients, and all of these were below the average weight of healthy children in social Class I (Institute of Child Health, Lagos Report 1963-68).

Of the 48 children, 39 presented as emergencies, and had been admitted to hospital earlier (Table I). All patients were from families of indigenous people.

In 41 patients blood was collected in a paraffin

Received 27 June 1969. bottle before the start of treatment for determination of serum sodium, potassium, chloride, and bicarbonate. In 7 patients blood samples were collected after they had received varying amounts of intravenous fluids (Cases 1-7, Table I).

\section{Results}

Most of the patients were brought to hospital between 3 and 7 days after the onset of illness. Gastro-enteritis was the most frequent provisional diagnosis, stools being watery and frequent: 5-10 times a day. Vomiting was frequent, especially after feeds. 3 patients were admitted with bronchopneumonia and diarrhoea; 4 had urinary tract infections; and 1 child, $3 \frac{1}{2}$ years old, had abdominal and pulmonary tuberculosis. Accurate records of fluid intake júst before and during the illness were available in only 9 in-patients and these are summarized in Table $\mathrm{I}$; of these, 4 patients were on intravenous fluids. One patient received $220 \mathrm{ml}$. Darrow's solution intraperitoneally. In Case 7 (Table I) the leakage of intravenous fluid was only discovered after 24 hours. 7 patients attended health centres and had received oral normal saline with glucose or Darrow's solution in unknown quantities. 34 patients, including Cases 8 and 9 (Table I), had received no fluids therapeutically, and during the illness had been fed on breast milk supplemented with milk recon- 
TABLE I

Fluid Intake in 9 Patients in First 24-48 Hours and During Illness

\begin{tabular}{|c|c|c|c|c|c|c|}
\hline Case No. & Sex/Age & Weight (g.) & $\begin{array}{l}\text { Immediate Cause } \\
\text { of Dehydration }\end{array}$ & $\begin{array}{l}\text { Initial Serum } \mathrm{Na} \\
\quad\left(\mathrm{mEq}^{\prime} \mathbf{l} .\right)\end{array}$ & Fluid Intake & $\begin{array}{l}\text { Max. Serum } \\
\text { Conc. (mEq }\end{array}$ \\
\hline 1 & $\star 9 \mathrm{mth}$. & 5443 & $\begin{array}{l}\text { Bronchopneu- } \\
\text { monia and } \\
\text { diarrhoea }\end{array}$ & 122 & $\begin{array}{l}0.9 \% \text { sodium } \\
\text { chloride } \\
\text { solution; } \\
2740 \mathrm{ml} \text {. in } \\
5 \text { days }\end{array}$ & 166 \\
\hline 2 & $\underset{5 \mathrm{mth}}{\mathrm{F}}$ & 5443 & $\begin{array}{l}\text { Diarrhoea and } \\
\text { vomiting }\end{array}$ & & $\begin{array}{l}250 \mathrm{ml} .0 .9 \% \\
\text { and } 500 \mathrm{ml} \\
\mathrm{N} / 2 \mathrm{NaCl} \\
\text { solution }\end{array}$ & 160 \\
\hline 3 & $\underset{9 \text { mth. }}{F}$ & & $\begin{array}{l}\text { Diarrhoea and } \\
\text { vomiting }\end{array}$ & 115 & $\begin{array}{l}1200 \mathrm{ml} .0 \cdot 9 \% \\
\mathrm{NaCl} \text { solution }\end{array}$ & 160 \\
\hline 4 & $\underset{1 \mathrm{yr}}{\mathrm{F}}$ & 4989 & $\begin{array}{l}\text { Diarrhoea and } \\
\text { vomiting, } \\
\text { kwashiorkor }\end{array}$ & & $\begin{array}{r}1460 \mathrm{ml} .0 \cdot 18 \% \\
\text { solution } \mathrm{NaCl}\end{array}$ & 162 \\
\hline 5 & $\underset{5 \mathrm{mth}}{\mathrm{F}}$ & 4535 & $\begin{array}{l}\text { Diarrhoea and } \\
\text { vomiting }\end{array}$ & 150 & $\begin{array}{l}220 \text { ml. full } \\
\text { strength } \\
\text { Darrows } \\
\text { solution intra- } \\
\text { peritoneally }\end{array}$ & 162 \\
\hline 6 & $\underset{1 \mathrm{mth}}{\mathrm{F}}$ & 4989 & $\begin{array}{l}\text { Diarrhoea and } \\
\text { vomiting }\end{array}$ & 150 & $\begin{array}{l}610 \mathrm{ml} .0 \cdot 18 \% \\
\text { saline }\end{array}$ & 162 \\
\hline 7 & $\underset{13 \text { mth. }}{F}$ & 5443 & $\begin{array}{l}\text { Diarrhoea and } \\
\text { vomiting }\end{array}$ & 131 & $\begin{array}{l}\text { Intravenous } \\
\text { fluid leaked; } \\
\text { no oral fluids }\end{array}$ & 148 \\
\hline 8 & $\underset{1 \mathrm{mth}}{\mathrm{F}}$ & 2550 & $\begin{array}{l}\text { Diarrhoea and } \\
\text { vomiting }\end{array}$ & & $\begin{array}{l}\text { F.S. Lactogen } \\
720 \mathrm{ml} . / 24 \mathrm{hr} \text {. }\end{array}$ & 160 \\
\hline 9 & $\begin{array}{c}\mathrm{F} \\
1 \mathrm{yr}\end{array}$ & 5556 & $\begin{array}{l}\text { Bronchopneu- } \\
\text { monia and } \\
\text { diarrhoea }\end{array}$ & 142 & $\begin{array}{l}\text { F.S. Lactogen } \\
540 \mathrm{ml} . / 24 \mathrm{hr} \text {. }\end{array}$ & 160 \\
\hline
\end{tabular}

$\star$ Sex not recorded.

stituted from powdered milk, in most cases Lactogen.

All except 5 children showed clear clinical signs of dehydration, often severe.

Thirty-one patients had fever of $37 \cdot 8^{\circ} \mathrm{C}$. or more; the temperature reached $40^{\circ} \mathrm{C}$. in 11 , and $41 \cdot 1^{\circ} \mathrm{C}$. in 2 . Hyperirritability was present in 31 patients; of these, 16 were irritable when disturbed though lethargic otherwise. Thirst was present in all except those who were very sick and comatose. Only 5 patients were in shock with thin radial pulse and cold extremities. In 14 patients pulse volume and peripheral circulation were noted as good despite signs of severe dehydration.

Thirty-seven patients had hyperpnoea with acidotic breathing. In 3 respiration was depressed and breathing shallow, in spite of a very low bicarbonate concentration in blood.

Cerebral symptoms were present in 22 patients $(46 \%)$. The salient features of these cases are summarized in Table II. Consciousness varied from hyperirritability to gross depression in 14 patients. 6 patients had generalized or focal convulsions. Involuntary movements, coarse tremors, and generalized hypertonia were present in 5. 6 patients showed signs of meningeal irritation such as neck stiffness, positive Kernig sign, and a shrill cry. In only 2 patients was the anterior fontanelle found to be tense. Subarachnoid haemorrhage was found in 2 patients.

Fourteen $(29 \%)$ out of the 48 patients died, all but one death occurring among patients wiकth CNS signs. 7 necropsies were carried out; 3 (Cases $5,13,14$, Table II) revealed petechial haemorrhages on the surface and in the substance of the brain, especially the cerebellum; numerous intravascular thrombi were found in 2 and massive intraventrotcular haemorrhage in 1 of them (Case 5, Table Iq; in the remaining 4, cerebral oedema and extreme vascular congestion were the main findings. In 02 of them microscopy showed oedema and severe hyperaemia with marked stasis in blood vessefs of meninges and extravasation of erythrocytes. These lesions were of the type known to be associo:ted with hypernatraemia (Finberg, Lutterell, and Redd, 1959; Finberg, Kiley, and Lutterell, 1963ी.

\section{Laboratory Investigation}

The results are given in Table III. The serum sodium concentration ranged from 148-175 mEq In 3 patients, the bicarbonate content of blood was above $20 \mathrm{mEq} / 1$; ; all others had significant metabolic 
TABLE II

Clinical Features in 22 Patients with CNS Signs

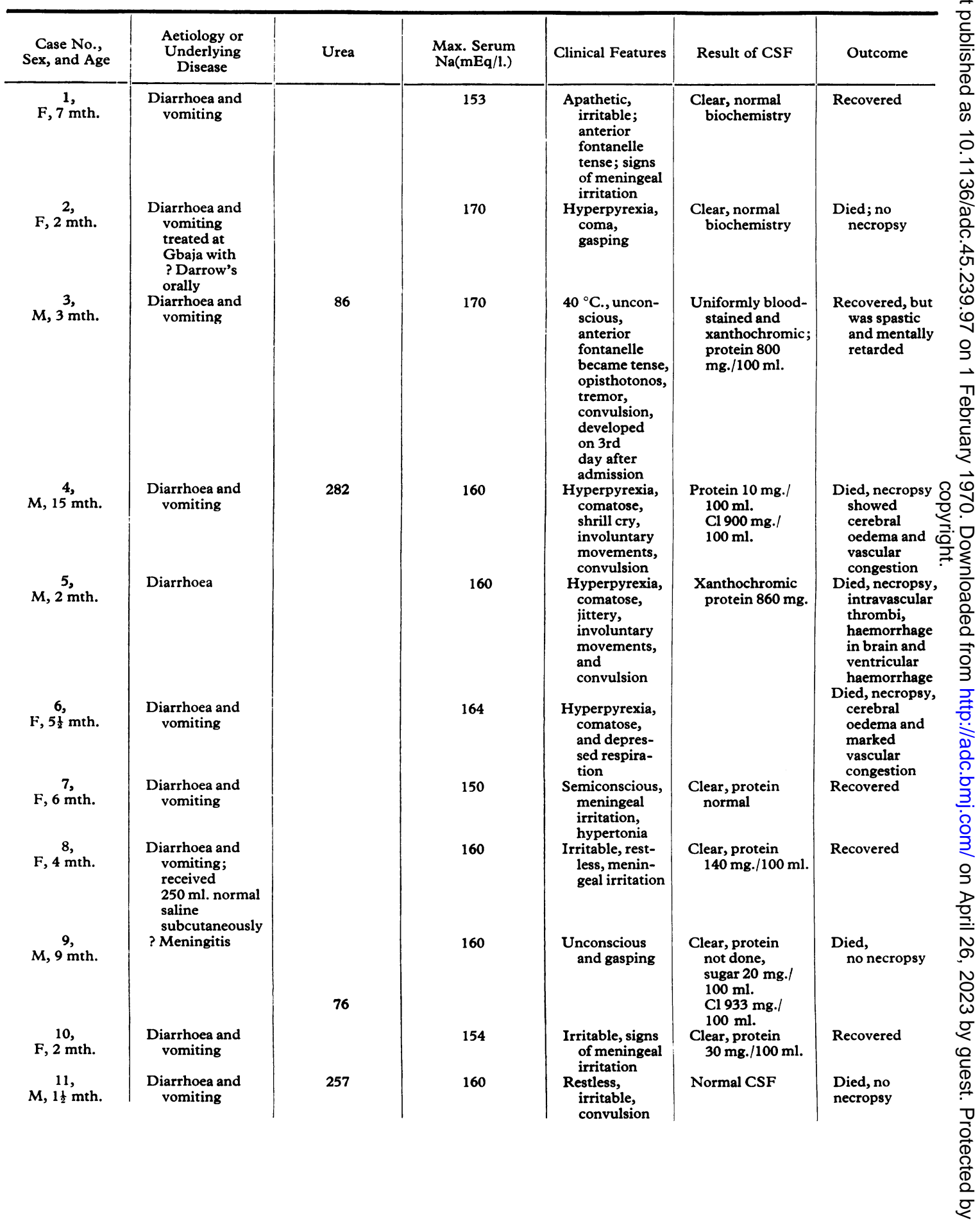


TABLE II-continued

\begin{tabular}{|c|c|c|c|c|c|c|}
\hline $\begin{array}{l}\text { Case No., } \\
\text { Sex, and Age }\end{array}$ & $\begin{array}{c}\text { Aetiology or } \\
\text { Underlying } \\
\text { Disease }\end{array}$ & Urea & $\begin{array}{r}\text { Max. Serum } \\
\mathrm{Na}(\mathrm{mEq} / 1 .)\end{array}$ & Clinical Features & Result of CSF & Outcome \\
\hline $\begin{array}{l}12, \\
M, 4 \text { mth. }\end{array}$ & $\begin{array}{l}\text { Diarrhoea and } \\
\text { vomiting, } \\
\text { urinary infec- } \\
\text { tion, IVP } \\
\text { non-function- } \\
\text { ing lt. kidney }\end{array}$ & 252 & 160 & $\begin{array}{l}\text { Comatose, } \\
\text { signs of } \\
\text { meningeal } \\
\text { irritation }\end{array}$ & $\begin{array}{l}\text { Protein } 100 \mathrm{mg} . / \\
\quad 100 \mathrm{ml} .\end{array}$ & 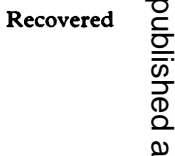 \\
\hline $\begin{array}{c}13 \\
\text { F, } 6 \text { mth. }\end{array}$ & $\begin{array}{l}\text { Diarrhoea and } \\
\text { vomiting }\end{array}$ & 114 & 150 & $\begin{array}{l}\text { Comatose, } \\
\text { restless, } \\
\text { convulsion }\end{array}$ & $\begin{array}{l}\text { Protein } 120 \mathrm{mg} . i \\
\quad 100 \mathrm{ml} .\end{array}$ & $\begin{array}{l}\text { Died; } \\
\text { oedema of } \\
\text { brain and } \\
\text { petechial } \\
\text { haemorrhage् } \\
\text { on the braine }\end{array}$ \\
\hline $\begin{array}{l}14, \\
M, 8 \text { mth. }\end{array}$ & $\begin{array}{l}\text { Diarrhoea and } \\
\text { vomiting }\end{array}$ & 42 & 158 & $\begin{array}{l}\text { Restless, } \\
\text { irritable, } \\
\text { neck } \\
\text { retraction }\end{array}$ & CSF normal & $\begin{array}{l}\text { surface } \\
\text { Died, } \\
\text { haemorrhage } \\
\text { on } \\
\text { surface and } \\
\text { in brain; } \\
\text { numerous } \\
\text { intravascula } \\
\text { thrombi }\end{array}$ \\
\hline $\begin{array}{l}15 \text {, } \\
\text { M,h. }\end{array}$ & $\begin{array}{l}\text { Diarrhoea and } \\
\text { vomiting }\end{array}$ & & 164 & $\begin{array}{l}\text { Semiconscious, } \\
\text { hypertonic;, } \\
\text { brisk reflexes, } \\
\text { bilateral } \\
\text { ankle clonus }\end{array}$ & & $\begin{array}{l}\text { Recovered; } \\
\text { CNS signs } \\
\text { cleared up } \\
\text { after recoverg }\end{array}$ \\
\hline $\begin{array}{l}16 \\
\text { F, } 13 \text { mth. }\end{array}$ & $\begin{array}{l}\text { Diarrhoea and } \\
\text { vomiting }\end{array}$ & & 148 & $\begin{array}{l}\text { Restless, thirst, } \\
\text { tremor of } \\
\text { hands }\end{array}$ & & $\begin{array}{l}\text { Died of } \\
\text { hyperkalae- } \\
\text { mia }\end{array}$ \\
\hline $\begin{array}{l}17 \\
M, 3 \frac{1}{2} \text { yr. }\end{array}$ & $\begin{array}{l}\text { A case of primary } \\
\text { TB; diarrhoea } \\
\text { and vomiting }\end{array}$ & & 166 & $\begin{array}{l}\text { Semiconscious, } \\
\text { hyper- } \\
\text { pyrexia, deep } \\
\text { acidotic } \\
\text { breathing }\end{array}$ & & $\begin{array}{l}\text { Died; } \\
\text { tubercul@s } \\
\text { lesions ing } \\
\text { lungs and } \\
\text { abdomefo } \\
\text { cerebral } \\
\text { oedema and } \\
\text { hyperaemia }\end{array}$ \\
\hline $\begin{array}{l}18, \\
M, 1 \frac{1}{2} \text { mth. }\end{array}$ & $\begin{array}{l}\text { Diarrhoea and } \\
\text { vomiting }\end{array}$ & & 158 & $\begin{array}{l}\text { Semiconscious, } \\
\text { restless, } \\
\text { head retrac- } \\
\text { tion, acidotic } \\
\text { breathing }\end{array}$ & $\begin{array}{l}\text { Protein } 100 \mathrm{mg} . / \\
\quad 100 \mathrm{ml} .\end{array}$ & 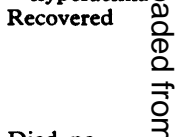 \\
\hline $\begin{array}{c}19, \\
F, 1 \text { yr. }\end{array}$ & $\begin{array}{l}\text { Broncho- } \\
\text { pneumonia; } \\
\text { malnourished }\end{array}$ & 54 & 160 & $\begin{array}{l}\text { Unconscious, } \\
\text { hypertonic, } \\
\text { convulsion }\end{array}$ & $\begin{array}{l}\text { Protein } 35 \mathrm{mg} . / \\
100 \mathrm{ml} .\end{array}$ & $\begin{array}{l}\text { Died, no } \\
\text { necropsy }\end{array}$ \\
\hline $\begin{array}{l}20 \\
\text { M, } 3 \text { mth. }\end{array}$ & $\begin{array}{l}\text { Diarrhoea and } \\
\text { vomiting }\end{array}$ & 64 & 160 & $\begin{array}{l}\text { Irritable; } \\
\text { slight } \\
\text { hypertonia }\end{array}$ & Protein raised & Recovered \\
\hline $\begin{array}{l}21 \\
\text { F, } 9 \text { mth. }\end{array}$ & $\begin{array}{l}\text { Diarrhoea and } \\
\text { vomiting }\end{array}$ & 52 & 166 & $\begin{array}{l}\text { Comatose, } \\
\text { hyperpyrexia, } \\
\text { ? carpopedal }\end{array}$ & & $\begin{array}{l}\text { Died, no } \\
\text { necropsy }\end{array}$ \\
\hline $\begin{array}{l}22 \\
M, 8 \text { mth. }\end{array}$ & $\begin{array}{l}\text { Diarrhoea and } \\
\text { vomiting }\end{array}$ & & 168 & $\begin{array}{l}\text { spasm } \\
\text { Comatose }\end{array}$ & & $\begin{array}{l}\text { Died, } \\
\text { necropsy: } \\
\text { cerebral } \\
\text { oedema and } \\
\text { congestion }\end{array}$ \\
\hline
\end{tabular}

acidosis. Potassium was above $6 \mathrm{mEq} / \mathrm{l}$. in 4 patients and below $3 \mathrm{mEq} / \mathrm{l}$. in 5 patients; none of the latter had signs of hypokalaemia.

Blood urea was estimated in 19 patients and ranged from 42 to $282 \mathrm{mg}$. $/ 100 \mathrm{ml}$.

Lumbar puncture was performed in 16 patients. CSF was uniformly blood stained and xantho- chromic in 2 patients (Case 3 and 5, Table II); others it was clear and under normal pressure. In 8 patients the protein content was high, ranging from 35 to $860 \mathrm{mg} . / 100 \mathrm{ml}$. Sugar was normal or increased in all specimens. Chloride was increased in all and ranged from 800 to $933 \mathrm{mg} . / 100 \mathrm{mft}$ (normal $750 \mathrm{mg} . / 100 \mathrm{ml}$.). 
TABLE III

Concentration of Electrolytes and Urea in Blood Serum

\begin{tabular}{|c|c|c|c|}
\hline & & Range & No. of Patients \\
\hline $\begin{array}{l}\mathrm{Na}(\mathrm{mEq} / \mathrm{l} .) \\
\mathrm{Cl}(\mathrm{mEq} / \mathrm{l} .) \\
\mathrm{HCO} \text { (mEq/l.) } \\
\mathrm{K}(\mathrm{mEq} / \mathrm{l} .) \text {.. } \\
\text { Blood urea (mg./ } \\
\quad 100 \mathrm{ml} .) \quad \ldots\end{array}$ & $\begin{array}{l}\ldots \\
\ldots \\
\ldots \\
\ldots\end{array}$ & $\begin{array}{c}148-175 \\
110-150 \\
6-25 \\
2 \cdot 4-7 \cdot 2 \\
42-282\end{array}$ & $\begin{array}{l}48 \\
42 \\
38 \\
39 \\
\\
19\end{array}$ \\
\hline
\end{tabular}

\section{Discussion}

Incidence. Hypernatraemic dehydration in diarrhoea is believed to be uncommon in the tropics. Ahmed and Webb (1963) found hypernatraemia in 1 single infant in a series of 65 infants presenting with diarrhoea at Vellore in South India and this infant had been given concentrated salt solution $(500 \mathrm{mEq} / \mathrm{l}$.) by mistake. A similar low incidence has been reported from Karachi (Zubeida et al., 1968, personal communication).

By contrast, in our experience at Lagos, hypernatraemic dehydration in infants with gastroenteritis is not uncommon. Of 643 patients with diarrhoea who attended the Casualty Department from June 1967 to January 1968, 120 had their serum sodium measured. In 25 of these, serum sodium was $150 \mathrm{mEq} / \mathrm{l}$. or more, an incidence of $20 \%$. A similar incidence of hypernatraemic dehydration in diarrhoeal infants has been reported from the U.S.A. and other Western countries (Darrow et al., 1949; Weil and Wallace, 1956; Finberg and Harrison, 1955; Bruck et al., 1968).

Hypernatraemic dehydration is commoner in infants under 1 year and this is well illustrated in two recent studies on hypernatraemia (MorrisJones, Houston, and Evans, 1967; Bruck et al., 1968). In the present series also all infants except 3 were under 1 year, and of these, $30(62 \%)$ were under 6 months.

Causes of hypernatraemic dehydration in infants. Hypernatraemia, i.e. serum sodium concentration of $150 \mathrm{mEq} / \mathrm{l}$. or more, is due to excessive loss of water from body fluids or to reduced intake of water in relation to electrolytes. It is more often due to a total deficit of water than to an excess of sodium. The potential channels of excessive loss of water in infants are insensible water loss through skin and respiratory passages, diarrhoeal stools, and dilute urine. In normal infants more than $50 \%$ of daily water loss is from the surface of the skin and the lungs, and fever, hyperventila- tion, and high environmental temperature tend to aggravate this loss. Heeley and Talbot (1955) observed average rates of insensible water loss of $1150 \mathrm{ml} . / \mathrm{m} .{ }^{2}$ per day in sick infants, which is considerably higher than those for resting healthy infants. The average rate of insensible water loss in resting well infants is about $470-620 \mathrm{ml} . / \mathrm{m} .{ }^{2}$ per day (Guest and Pettit, 1957).

Diarrhoeal stools are usually hypotonic when compared with blood. If the stools are large and frequent there is proportionately a greater loss of water than sodium (Skinner and Moll, 1956; Weil and Wallace, 1956; Bruck et al., 1968).

Insufficient water intake. This is common in infants. In the present series, all patients except 4 (Table I, Cases $1,2,3,4$ ) had received insufficient quantities of water during the acute illness because of vomiting and anorexia.

Increased renal water requirement. Because of renal immaturity, dehydrated young infants are unable to form maximally concentrated urine. If they are fed on undiluted cow's milk and skimmed powder milk mixture which provides high protein intake, or given saline orally or parenterally, which gives a high solute load, the renal water requirement obligatory for excretion of electrolytes and urea is increased, thus increasing the water deficit (Pratt and Snyderman, 1953). 37 of 48 patients in the present series continued to be fed on powdered milk mixture in addition to breast feeding during the illness. It is possible that this could have contributed to the water deficit and to the hypertonicity of the blood.

In the majority of our patients no single cause could be identified as being responsible for the hypertonicity of the body fluids. A combination of several factors related to acute illness, i.e. water loss in a hypotonic diarrhoeal stool, excessive insensible water loss, insufficient water intake, and continued feeding of infants on powdered milk mixture in addition to breast-feeding accounted for or contributed to hypernatraemia. The rarity of this condition in India and Pakistan could be explained by the fact that mothers as a rule stop all feeds, including milk, and give only sugar and barley water to infants with diarrhoea.

Excessive administration of salt solution was the probable cause of hypernatraemia in only 11 of 48 patients. Of these, 4 patients (Cases $1,2,3,4$, Table I) had received large amounts of salt solution intravenously, while 7 patients, who were referred from Health Centres, had received orally unknown quantities of isotonic $\mathrm{NaCl}$ solution or Darrow's solution.

Cerebral manifestations in association with acute 
hypernatraemia are common and well documented (Rapoport, 1947; Finberg and Harrison, 1955; Skinner and Moll, 1956; Weil and Wallace, 1956; Macaulay and Blackhall, 1961; Morris-Jones et al., 1967), and subdural and subarachnoid haemorrhages have been observed in infants with hypernatraemia (Finberg, 1959). These clinical observations have been amply confirmed experimentally (Finberg et al., 1959), and experimental studies have also shown that the osmolality of the extracellular fluid is the relevant factor rather than the sodium concentration alone (Finberg et al., 1959). Thus, when a hypertonic solution, whether of sodium chloride, sodium bicarbonate, sucrose, mannitol, or urea, was injected into laboratory animals, cerebral lesions were produced which were closely akin to those found in human beings. MorrisJones et al. (1967) showed a close relation between frequency of fits and serum sodium levels; thus the risk of fits was $10 \%$ when serum sodium was in the range of 140 to $158 \mathrm{mEq} / 1$. but $71 \%$ at serum sodium levels above $158 \mathrm{mEq} / \mathrm{l}$. The danger was further increased when high blood urea levels also contributed to extracellular osmolality.

Accepting the standard of Morris-Jones et al. (1967), that a serum $\mathrm{Na}$ concentration of $158 \mathrm{mEq} / \mathrm{l}$. indicates severe hypernatraemia, $65 \%(17 / 26)$ of such patients in the present series had cerebral symptoms. 15 of these 17 had symptoms of severe cerebral disturbances, such as coma, convulsions, generalized hypertonia, gross involuntary movements, and neck retraction, whereas when the serum sodium level was below $158 \mathrm{mEq} / 1 ., 27 \%(5 / 22)$ of the patients had cerebral signs, and only one of them (Case 13, Table II) was unconscious and had convulsions. It is, therefore, clear that cerebral disturbances are correlated with high serum sodium concentration $\left(X^{2}=8 \cdot 7, \mathrm{p}<0 \cdot 01\right)$ (Fig.).

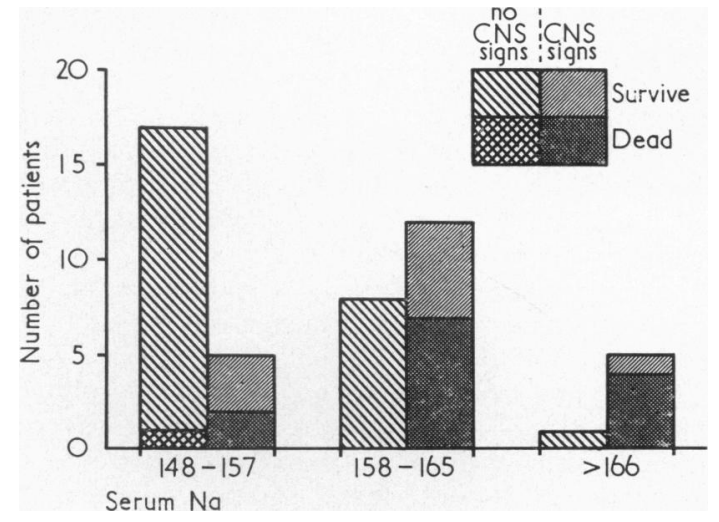

FIG.-Serum $N a(m E q / l$.) in 48 patients related to CNS signs and death.
Macaulay and Watson (1967) in a followreport on 100 hypernatraemic patients, who had 120 antecedent nervous disease, found that 16 patients had sustained permanent brain damage and of these only 8 patients were alive. Morris-Jones et at. (1967) reported neurological abnormalities in 37 $(12 / 32)$ of the survivors; in several, howevets abnormalities were unrelated to earlier hype natraemia, and only 3 out of $32(9 \%)$ had bot related and symptomatically important lesions. Several other authors (Finberg, 1959; Weil and Wallace, 1956) have also reported permanent brain damage among survivors from acute hypernatra $\overrightarrow{e_{0}}$ mic dehydration.

In the present series neurological signs we present in $22(46 \%)$ of 48 patients, and of thesi 13 died, though in one (Case 16, Table II) hyper kalaemia was the probable cause of death. If patients who, at the time of admission, had siges of severe brain damage, showed no improvement on treatment; coma deepened, respiration became irregular, and death followed. Of the 9 survivors 1 child (Case 3, Table II) sustained permanegt brain damage. 3 other children have been followed for one year and so far their physical and mental development have been normal.

\section{Conclusions}

This study shows that hypernatraemic dehy tion is not infrequent in Lagos in infants suffering from diarrhoea. In our experience the clinical features that helped us to arrive at a diagnosiss of this condition were: pyrexia, often high, hype: irritability, lethargy, increased thirst, absence of shock, good peripheral circulation in spite of mode? ate to severe dehydration, and presence of acidotic respiration.

In view of the high risk of brain damage and mortality attendant on this condition, it is imporofant to prevent hypernatraemia. In the majori of patients hypernatraemia results from excessive loss of water in relation to sodium, and it can bee prevented by ensuring an adequate fluid intake in am infant who has fever and is hyperventilating especially when diarrhoea is also present. The daily fluid requirement of a normal infant is approxi: mately $150 \mathrm{ml}$. $/ \mathrm{kg}$. body weight in 24 hours. More may be needed in hot climates. During the diar? rhoeal illness, twice the normal intake may bo necessary. Injudicious administration of fluids with a high solute content such as $0.9 \% \mathrm{NaQ}$ solution with $5 \%$ dextrose, or Darrow's solution should be discouraged. Mothers should be adviserd to stop milk feeds during the illness, and instead to offer the infant at frequent intervals a solutiog 
containing sodium chloride $0.85 \mathrm{~g}$., $\mathrm{KHCO}_{3} 1 \mathrm{~g}$., and sugar $25 \mathrm{~g}$. in a pint of water. If the diarrhoea continues and the child cannot take the fluids because of anorexia and vomiting, intravenous fluids will have to be given and this will necessitate admission to hospital.

We thank Professor Ransome-Kuti, Ag. Head of the Department of Paediatrics, College of Medicine of the University of Lagos, and Professor John Davis of Manchester for their help and advice in preparing this paper, and Dr. Odunjo of the Department of Pathology, College of Medicine of the University of Lagos, for giving us the results of the necropsy. We are also grateful to our other colleagues for allowing us access to their patients.

\section{REFERENCES}

Ahmed, I., and Webb, J. K. G. (1963). Childhood diarrhoea in S. India with particular reference to fluid and electrolyte disturbance. Indian fournal of Child Health, 12, 85.

Bruck, E., Abal, G., and Aceto, T., Jr. (1968). Pathogenesis and pathophysiology of hypertonic dehydration with diarrhea: a clinical study of 59 infants with observations of respiratory and renal water metabolism. American fournal of Diseases of Children, 115, 122.

Darrow, D. C., Pratt, E. L., Flett, J., Jr., Gamble, A. H., and Wiese, H. F. (1949). Disturbances of water and electrolytes in infantile diarrhea. Pediatrics, 3, 129.

Finberg, L. (1959). Pathogenesis of lesions in the nervous system in hypernatremic states. I. Clinical observations of infants. Pediatrics, 23, 40.
- and Harrison, H. E. (1955). Hypernatremia in infants. Pediatrics, 16, 1.

—, Kiley, J., and Lutterell, C. N. (1963). Mass accidental salt poisoning in infancy. Fournal of the American Medical Association, 184, 187.

_ Lutterell, C., and Redd, H. (1959). Pathogenesis of lesions in the nervous system in hypernatraemic states. II. Experimental studies of gross anatomic changes and alterations of chemical composition of the tissues. Pediatrics, 23, 46.

Guest, G. M., and Pettit, M. D. (1957). Apparatus for continuous recording of insensible weight loss. Proceedings of the Federation of American Societies for Experimental Biology, no. 389, (abstract, Federation Proceedings, 16, 189).

Heeley, A. M., and Talbot, N. B. (1955). Insensible water losses per day by hospitalized infants and children. American Fournal of Diseases of Children, 90, 251.

Macaulay, D., and Blackhall, M. I. (1961). Hypernatraemic dehydration in infantile gastro-enteritis. Archives of Disease in Childhood, 36, 543.

- , and Watson, M. (1967). Hypernatraemia in infants as a cause of brain damage. Archives of Disease in Childhood, 42, 485.

Morris-Jones, P. H., Houston, I. B., and Evans, R. C. (1967). Prognosis of the neurological complications of acute hypernatraemia. Lancet, 2, 1385.

Pratt, E. L., and Snyderman, S. E. (1953). Renal water requirement of infants fed evaporated milk with and without added carbohydrate. Pediatrics, 11, 65.

Rapoport, S. (1947). Hyperosmolarity and hyperelectrolytemia in pathologic conditions of childhood. American fournal of Diseases of Children, 74, 682.

Skinner, A. L., and Moll, F. C. (1956). Hypernatremia accompanying infant diarrhea. American fournal of Diseases of Children, $92,562$.

Weil, W. B., and Wallace, W. M. (1956). Hypertonic dehydration in infancy. Pediatrics, 17, 171. 